\title{
DEVELOPMENT AND EVALUATION OF RICE TRANSPLANTING MACHINE TO USE AS SPRAYING FOR COTTON CROP \\ ${ }^{1}$ Samir Tayel* \\ Osama Kamel ${ }^{* *}$ \\ Abd El-Kader El-Nakib* \\ A.G.Soliman***
}

\section{ABSTRACT}

The research are developed design and constructed a prototype mechanism attached with a transplanter and used as a power source in the same time, in order to increase its efficiency. The sprayer was tested at four different spray heights, four different spray pressures, three different orifice diameter and four different nozzle spaces.

The maximum values of coefficient of uniformity were 75.78, 78.60 and $77.22 \%$ at orifice diameters of 0.50,1.0, and $1.5 \mathrm{~mm}$, respectively, with spray height of $700 \mathrm{~mm}$ and spray pressure of $500 \mathrm{kPa}$.

It is clear that the maximum values of coefficient of symmetry were obtained with the orifice diameter of $1.0 \mathrm{~mm}$. The highest values of coefficient of symmetry were 91.66, 93.16, 94.50and 95.50 \% at spray heights of 400,500,600, and $700 \mathrm{~mm}$, respectively, with spray pressure of $500 \mathrm{kPa}$ and orifice diameter of $1.0 \mathrm{~mm}$.

The maximum values of coefficient of uniformity were $78.75,83.15,84.75$ and $81.15 \%$ with nozzle spaces of 300,400,500, and $600 \mathrm{~mm}$, respectively, at spray height of $700 \mathrm{~mm}$ and spray pressure of $500 \mathrm{kPa}$. While the total costs for spraying operation was 20.45, and $21.56 \mathrm{LE} / \mathrm{h}$ ( 13.4 and 14.1 LE/fed) with the same above twice forward speeds.

\section{INTRODUCTION}

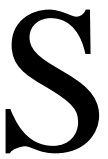

praying process and atomization of the liquids are considered the important means in agricultural utilization such as pest control, fertilization, and distribution of field substance. The farmers and growers turn to the application of pesticides to fight pests and weeds since they either feed on agricultural crops or act as vectors of disease and cause major losses of yield and quality.

Improving the spray distribution and deposition efficiency of spraying machines has been the goal of the present research. The results of

\footnotetext{
* Agric. Eng., Faculty of Agric., Al-Azhar University

** Head Researcher, Agic.Eng. Res. Inst. **** Agric. Eng., Agic.Eng. Res. Inst. ${ }^{1}$
} 
the previous investigation showed that the uniformity of distribution (application) is affected by a host of factors such as spray pressure, height, droplet size, the forward speed of the sprayer and characteristics of the spraying liquid. Therefore, the main objectives of the present study were: Developed and evaluate of sprayer prototype using the power unit of the prime mover of Yanmar ARP-8 Rice Transplanter to meet the demands of small and medium farmers in Egypt to control weeds, insects and diseases for different crops.

Badawy (1997) studied the effect of nozzle pressure (103, 138, 207, and $276 \mathrm{kpa}$ ) and nozzle spacing 510 and $670 \mathrm{~mm}$ on distribution pattern and deposit efficiency with different types of nozzle. He added that, all nozzles tested had coefficients of variation lower than $15 \%$. He found that the spray deposition increased by pressure increasing.

Pergher et al. (1999) studied the effect of forward speed on deposition in an asparagus crop. They used two levels of forward speed, low $(0.83 \mathrm{~m} / \mathrm{s})$ and high $(1.69 \mathrm{~m} / \mathrm{s})$. They found that deposition was not affected by the forward speed relative to travel direction. The most uniform deposition was obtained with forward speed of $1.69 \mathrm{~m} / \mathrm{s}$.

El-Metwally, (2001) manufacture a local self-propelled sprayer with cured and local ability for spraying insects and disease pest control. It suits for spraying crop and orchard fields. Field efficiency and the field productivity for the self-propelled sprayer at spray swath $4.8 \mathrm{~m}$ and speed $2.5 \mathrm{~km} / \mathrm{h}$ were $70 \%, 2 \mathrm{fed} / \mathrm{h}$, respectively.

Gad, (2005) design and construct an automatic control boom sprayer device of spraying height above the plant surface. He found that the sprayer forward speed of $2.2 \mathrm{~km} / \mathrm{h}$ recorded the height percentages of mortality for all the spray angles, nozzle height and operating pressures. However, the percentage of mortality decreased by $6.03 \%$ as a result to of increasing the forward speed from 2.20 to $5.89 \mathrm{~km} / \mathrm{h}$ at spray angle of $65 \mathrm{deg}(1.135 \mathrm{rad})$, nozzle height of $45 \mathrm{~cm}$ and operating pressure of $200 \mathrm{kpa}$.

El-Meseery and Abd-Fattah (2005) compared and evaluate two sprayers for controlling weed in wheat crop. The results indicated that the knapsack spryer

is better than Mist blower sprayer for weed control in wheat crop. The Knapsack sprayer gave an average deposit of 220 droplet $/ \mathrm{cm}^{2}, 145$ micron V.M.D., $82 \%$ uniformity, $85 \%$ weed control efficiency, 2.4 
ton/fed. Wheat yield and $6 \mathrm{LE}$ cost save comparing with the Mist blower. While the Mist blower gave average droplet of 150 deposit $/ \mathrm{cm}^{2}$ 150 micron V.M.D., 40\% uniformity, $77 \%$ weed control efficiency and 1.4 ton/fed wheat yield.

\section{MATERIALS and METHODS}

The main purpose of this study is to develop and evaluate of sprayer prototype using the power unit of the prime mover of Yanmar ARP-8 Rice Transplanter to meet the demands of small and medium farmers in Egypt to control weeds, insects and diseases for different crops. On the other hand, the use of a Rice Transplanter as a source of power. The oil pump for raising the seedling trays of transplanter up and down was used a source of power to operate spraying unit. However, the seedling trays of transplanter was separated and the transplanter equipped with pressure regulator which connected to hydraulic motor to convert the oil pressure into rotational movement to be suited for operating herbicide spraying pump was considered in the design of the proposed sprayer to realizing the goal of intensification use of farm machinery.

\section{Materials:-}

The materials and equipment used in this study may be indicated as follows: - Modified sprayer unit:

The spraying unit consists of frame, transmission power drive and shield as shown in Fig 1and 2 these components are explained as follows:

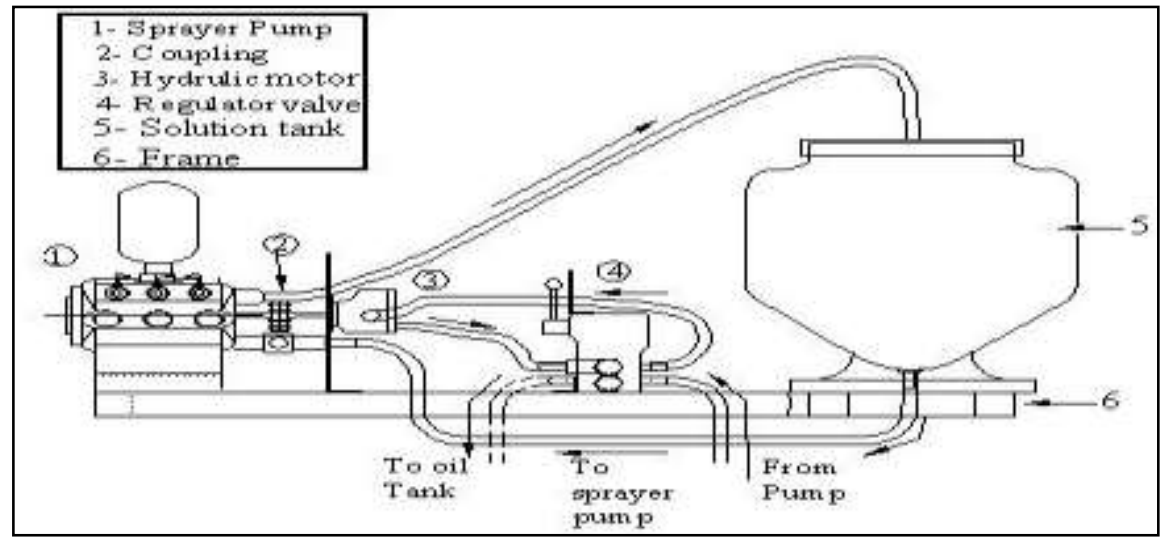

Fig. 1: The modified sprayer unit. 


\section{a)Frame sprayer unit:}

Argetnguler frame is made from steel angles section of $5 \times 5 \mathrm{~cm}$, thickness $0.3 \mathrm{~cm}$ and dimensions of $94,50 \mathrm{~cm}$, it is used as a frame for carrying the sprayer parts .

\section{b) Transmission power drive:}

The transplanter oil pump is used as a source of power to operate the spraying pump.

\section{c) Sprayer liquid tank:}

A corrosion-resis-tank of fiberglass was used to contain the spraying liquied,it has a large opening to allow easy filling plus a drain to construct cleaning. The tank capacity is about 100 liters. During dveloping and manfuctring the spraying unit it consider the simplisty and cheapness. It is simple in use, easy to assambling and easy to adjust. The discharge and nozzle spacing. Fabracting to machine and preliminary test wass carried out.

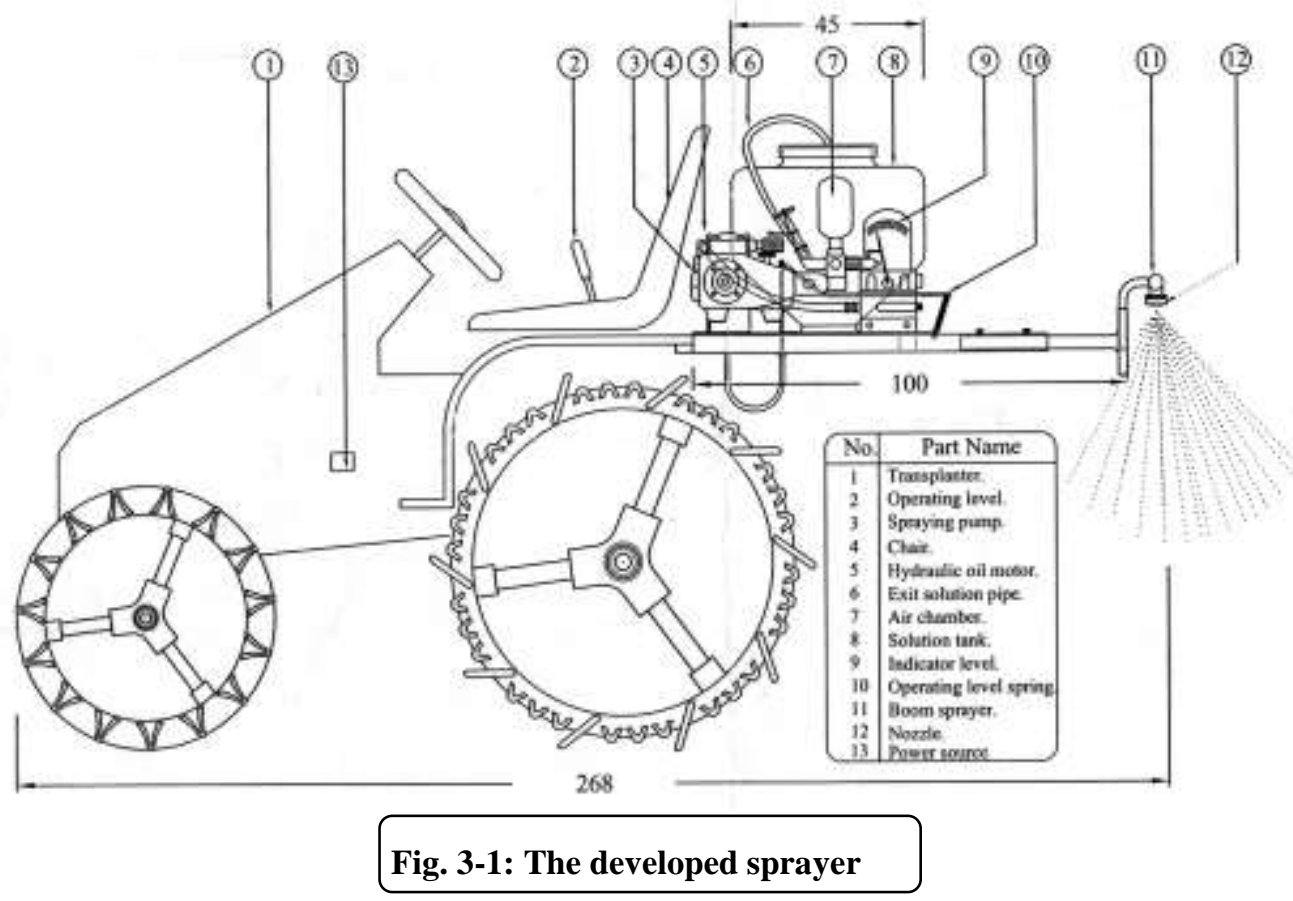

\section{d) Gear pumps}

A gear pump is attached with the transplanter used to pumping the hydrulic oil to operate the gear motor.

e) Regulator (control) valve

The $16^{\text {th }}$. Annual Conference of the Misr Society of Ag. Eng., 25 July, 2009 
A regulator valve is attached in the hydraulic circuit located between the hydraulic pump and hydraulic motor to regulated the oil pressure .

\section{f) Gear motors}

A gear motors fitted to the sprayer pump used as the power source. Oil under pressure flow inter the motor though the inlet, the oil then acts agents the fear wheels causing then to rotate thus turning the motor drive shaft. When the oil has spent its energy inturning the motor its discharged through the motor outlet and so back to tank.

\section{g) Sprayer pump:}

A three pistons pump is used to generate the pressure to the spring. It consists of 3 pistons, 3 cylinders, cylinder packing, delivery valves, connecting rode, crank, main shaft.

\section{Methods and Measurements:}

This research has been carried out in the laboratory of R.M.C., Meet ElDyba, Kafr El-Sheikh, Governorate during season of 2005 to study the effect of nozzle height, nozzle pressure, orifice diameter, spacing nozzle and sprayer forward speed on the spray distribution pattern of the sprayer. Tests were conducted at the following nozzle height of 400,500,600, and $700 \mathrm{~mm}$, nozzle pressure of $200,300,400$, and $500 \mathrm{kPa}$, orifice diameters of $0.50,1.0$, and $1.5 \mathrm{~mm}$, spacing between nozzle on boom sprayer of 300 , 400,500 , and $600 \mathrm{~mm}$ and two sprayer forward speeds of 1.5 and $2.2 \mathrm{~km} /$ h. All experiments were run by using water under room temperature and under approximately constant relative air humidity. The laboratory calibration tests includes determination of discharge rate, distribution pattern and spray deposition.

\section{Spray deposit efficiency:}

The spray efficiency was calculated as follow (Badawy,1997);

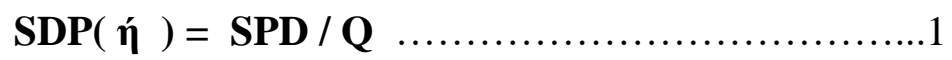

Where:

$\mathrm{SPD}=$ Amount of spray retained by plant $(\mathrm{L} / \mathrm{min})$.

$$
\mathrm{Q}=\text { The amount applied per plant }(\mathrm{L} / \mathrm{min}) \text {. }
$$

$\mathrm{Q}$ was calculated by using the following equation:

$$
Q=252 \times q / b \times v \times n
$$

Where: 
put, L/min,)

$\mathrm{Q}=$ Pump output, L / min, ( Number of nozzle $\mathrm{x}$ nozzle through

$$
\begin{aligned}
& \mathrm{b}=\text { Swath width }, \mathrm{m} . \\
& \mathrm{v}=\text { forward speed, } \mathrm{km} / \mathrm{h}, \text { and } \\
& \mathrm{n}=\text { Number of plant. }
\end{aligned}
$$

\section{Spray deposit uniformity (U):}

Spray deposit uniformity was investigated by using the following equation ( Dragos, 1975).

$$
\mathrm{U}=\mathbf{1 0 0}-\mathbf{C . V}, \boldsymbol{\%} \ldots \ldots \ldots \ldots \ldots \ldots \ldots \ldots \ldots \ldots \ldots
$$

\section{Coefficient of symmetry:}

The coefficient of symmetry ( $\mathbf{C}$ ) of spraying pattern were calculated according to the (Sayed Ahmed, 1989):

$$
\mathbf{C}=\mathbf{1}-(\mathbf{Z R}-\mathbf{Z L}) / \mathbf{Z T}, \ldots \ldots \ldots \ldots \ldots \ldots \ldots \ldots . .4
$$

Where :

$$
\begin{aligned}
\mathrm{ZR}, \mathrm{ZL}= & \text { Volume of spray collected from the right and left } \\
& \text { sides of the nozzle center line, } \mathrm{L} \text { and }
\end{aligned}
$$

\section{Calculating droplets numbers using microscope:}

The conventional microscope was used to calculate droplet numbers on the water sensitive card for every treatment. S and St series of wide field droplet numbers that were taken from area of the field microscope were calculated for one $\mathrm{cm}^{2}$.

\section{Calculating the droplet surface mean diameter:}

Droplet surface mean diameter (DSMD) is the mean of longitudinal and horizontal diameters of droplet. Micrometry slit was used to measure the longitudinal and lateral diameters of the spray droplets. Then the droplet surface mean diameter was calculated using the following equation:

DSMS = DX + DY / 2 .5

Where:

$\mathrm{DX}=$ The longest distance in the longitudinal direction (um)

$\mathrm{DY}=$ The longest distance in the lateral direction (um). 


\section{Field experiments:}

\section{Wheel sprayer slip percentage (S)}

Wheel slip is one of the most important sources of soil and traction efficiency during machinery operation. Wheel slip changes as a function of tire conditions and wheel load soil.

$$
\mathrm{S}, \%=\mathrm{L}-\mathrm{L} 1 / \mathrm{L} \times 100
$$

Where:

$$
\mathrm{L}=\text { Distance spent without load, } \mathrm{m} \text {, and }
$$

$\mathrm{L} 1=$ Distance spent with load, $\mathrm{m}$.

\section{Percentage of damaged plants (D.P.):}

It was calculated after carrying out the field experiment for the sprayer. Under the field conditions, its concluded that the main waste plants occurred in the start and end of the spray trip.

\section{Measurement of mortality percentage:-}

The population of worms calculated and evaluated after spraying operation for forty cotton plants in each treatment. The number of dead and alive worms in each treatment were counted after 72 hour from the spraying operation. The mortality percentage was assessed and estimated for each treatment .

\section{Power consumption, kW,(EP):}

measuring the decrease in fuel level in the fuel tank using a graduated flask. The following formula was used to estimate the engine power.

$$
\mathrm{EP}=\frac{\mathrm{Fc} \times \rho_{\mathrm{r}} \times \mathrm{L} . \mathrm{C} . \mathrm{V} \times 4270 \times \eta_{t h} \times \eta_{m}}{3600}, \mathrm{~kW}-\cdot-\cdot-\cdot-\cdot-\cdot-\cdot-\cdot---7
$$

Where:

Fc $\quad=$ Fuel consumption, $\mathrm{L} / \mathrm{h}$;

L.C.V = Lower calorific value of fuel $(11030 \mathrm{~kJ} / \mathrm{kg}$ for gasoline fuel);

$\mathrm{p}_{\mathrm{f}} \quad=$ Density of the fuel $(0.73 \mathrm{~kg} / \mathrm{l}$ for gasoline fuel $)$;

$4270=$ Thermal-mechanical equivalent, $\mathrm{kg} . \mathrm{m} / \mathrm{kcal}$;

$\dot{\eta}_{\text {th }} \quad=$ Thermal efficiency of engine (35\% for gasoline engine), and

$\eta_{\mathrm{m}} \quad=$ Mechanical efficiency of engine $(80 \%$ for gasoline engine).

\section{Cost analysis:}

The methodology of estimating spraying costs (LE/h) or (LE/fed) was as follow (Hunt, 1983). 
Total cost $(\mathrm{LE} / \mathrm{h})=$ Fixed cost $(\mathrm{LE} / \mathrm{h})+$ Variable cost $(\mathrm{LE} / \mathrm{h} \ldots \ldots \ldots 8$

Total cost $(\mathrm{LE} / \mathrm{fed})=$ Total cost $(\mathrm{LE} / \mathrm{h}) /$ Field capacity $(\mathrm{fed} / \mathrm{h} \ldots \ldots 9$

\section{RESULTS and DISCUSSIONS}

\section{Effect of spray height, spray pressure and orifice diameter on}

\section{the following indicators:}

\section{Coefficient of symmetry:}

The best uniform of distribution pattern was obtained at the maximum values of the coefficient of symmetry.

Fig.3 demonstrates the effect of spray height, spray pressure and orifice diameter on the coefficient of symmetry of the distribution pattern. It can be noticed that the obtained values of coefficient of symmetry were found to be $91.66,93.16,94.50$ and $95.50 \%$ at spray heights of 400,500,600 and $700 \mathrm{~mm}$, respectively, with spray pressure of $500 \mathrm{kPa}$ and orifice diameter of $1.0 \mathrm{~mm}$. The other spray pressures and orifice diameters have the same above mentioned trend.

It is clear that the spray pressures of $200,300,400$ and $500 \mathrm{kPa}$ gave the following values of coefficient of symmetry 83.63, 85.50, 87.71 and 90.00 $\%$, respectively, at spray height of $400 \mathrm{~mm}$ and orifice diameter of $1.5 \mathrm{~mm}$. The other spray heights and orifice diameters have the same above mentioned trend.

The orifice diameter of $0.50,1.0$ and $1.5 \mathrm{~mm}$ gave coefficient of symmetry values of 93.00, 95.50 and $93.62 \%$, respectively, at spray height of 700 $\mathrm{mm}$ and spray pressure of $500 \mathrm{kPa}$. The other spray heights and pressures have the same above mentioned trend.

\section{Coefficient of uniformity:}

The best uniform of the distribution pattern was obtained at the maximum values of coefficient of uniformity. Fig.4 indicated the effect of spray height, spray pressure and orifice diameter on the coefficient of uniformity of the distribution pattern. The spray heights of 400,500,600, and $700 \mathrm{~mm}$ gave coefficient of uniformity of $41.72,50.11,60.23$ and $69.52 \%$, respectively; with spray pressure of $200 \mathrm{kPa}$ and orifice diameter of 1.5 $\mathrm{mm}$. The other spray pressures and orifice diameters have the same above mentioned trend. 

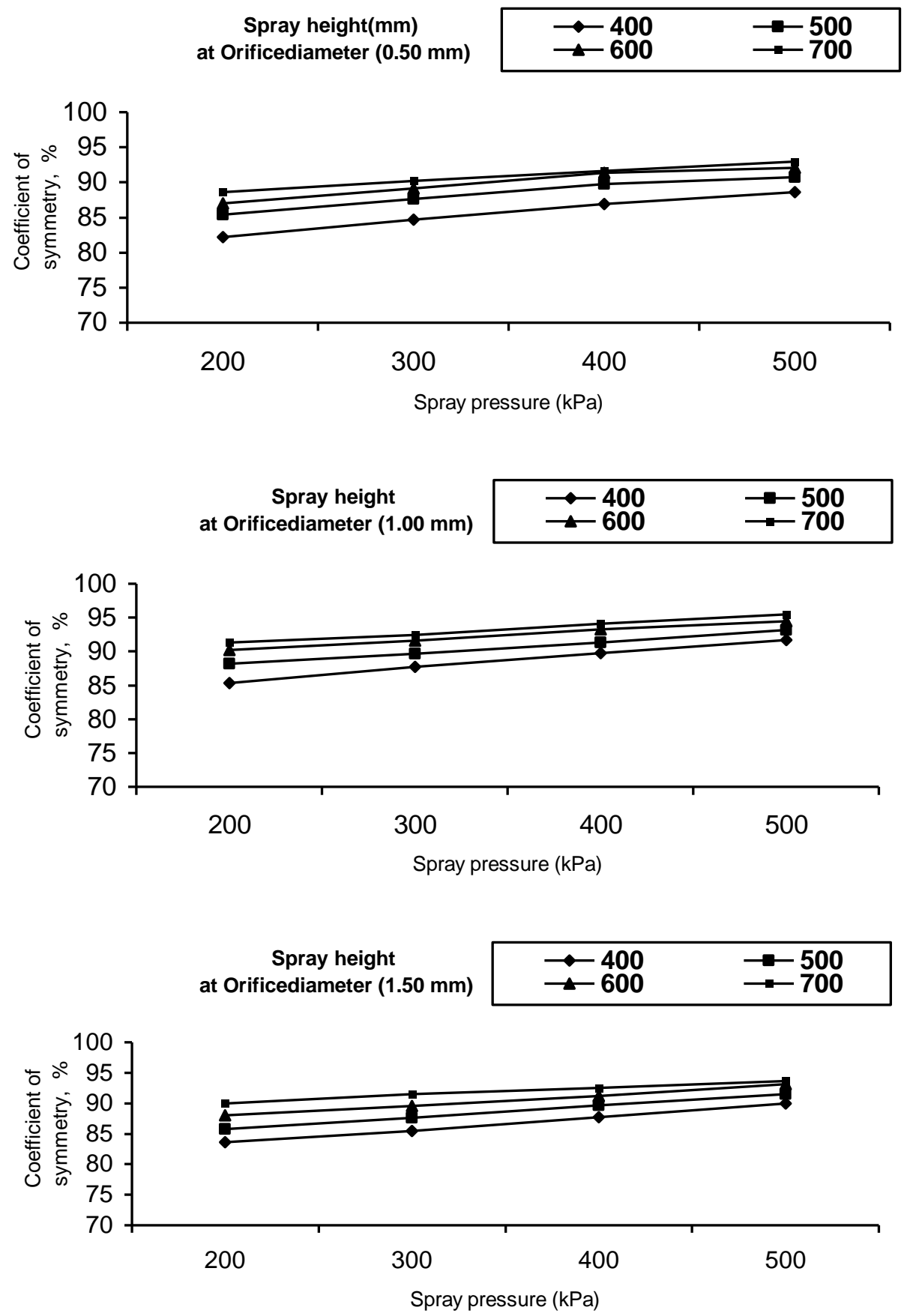

Fig. (3):-Effect of spray pressure, orifice diameter and spray height on the percentage of coefficient of symmetry at $500 \mathrm{~mm}$ nozzle space. 

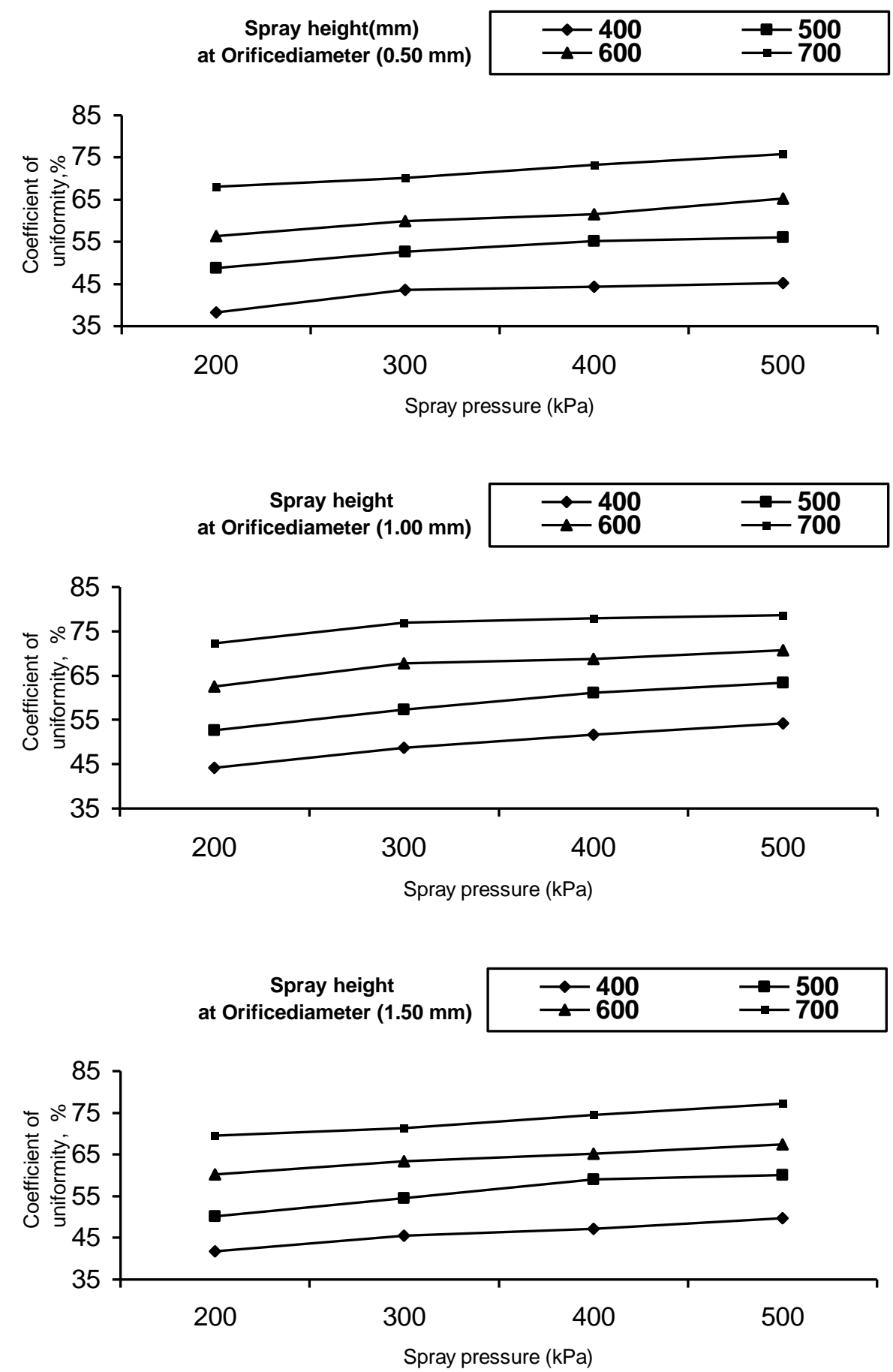

Fig. (4):-Effect of spray pressure, orifice diameter and spray height on of coefficient of uniformity at $500 \mathrm{~mm}$ nozzle space.

The $16^{\text {th }}$. Annual Conference of the Misr Society of Ag. Eng., 25 July, 2009 
The obtained values of coefficient of uniformity were found to be 68.11, $70.10,73.30$ and $75.78 \%$ at spray pressures of 200,300,400 and $500 \mathrm{kPa}$, respectively, with spray height of $700 \mathrm{~mm}$ and orifice diameter of $0.50 \mathrm{~mm}$. The other spray heights and orifice diameters have the same above mentioned trend.

It is noted that the orifice diameters of $0.50,1.0$ and $1.5 \mathrm{~mm}$ gave coefficient of uniformity of $61.61,68.82$ and $65.11 \%$, respectively, with spray height of $600 \mathrm{~mm}$ and spray pressure of $400 \mathrm{kPa}$. The other spray heights and spray pressures have the same above mentioned trend. However, the orifice diameter of $1.0 \mathrm{~mm}$ gave the maximum values of coefficient of uniformity compared with the other orifice diameters 0.57 and $1.5 \mathrm{~mm}$ for all the spray heights and pressures.

\section{Spray droplets number using microscope:}

Table 1 demonstrates the effect of spray pressure and orifice diameter on spray droplets at two different forward speed. The results indicated that increasing spray pressure increased spray droplet for both orifice diameter and forward speed. However, increasing orifice diameter decreased the spray droplet for two forward speeds with all spray pressure. It is noticed that the maximum values of droplet number were obtained with the orifice diameter $0.50 \mathrm{~mm}$ for all the spray pressure and forward speed. The data showed that the number of droplets on the upper surface of leaves was better than droplet numbers at lower surface.

Data presented in Table 2 show that the effect of forward speed and nozzle spacing on deposit ( number of droplet $/ \mathrm{cm}^{2}$ ). The data showed that increasing the forward speed decreased number of droplet $/ \mathrm{cm}^{2}$ with different nozzle spacing. The data showed that the numbers of droplets on the upper surface of leaves was better than droplet numbers at lower surface. The nozzle spacing $300 \mathrm{~mm}$ and forward speed of $1.5 \mathrm{~km} / \mathrm{h}$ gave the best droplet numbers (390 and $250 \mathrm{droplet} / \mathrm{cm}^{2}$ ) at the upper and lower surface of leaves.

\section{Droplets surface mean diameter (DSMD):}

Droplet surface mean diameter is the longitudinal and lateral diameter of droplets. Micrometry slit was used to measure the lateral and longitudinal diameter of the spray droplets. Then the droplets mean diameter was calculated. 
Droplet mean diameter is affected by spray pressure and orifice diameter at two forward speeds. Table 3 observed that the orifice diameter $0.50 \mathrm{~mm}$ gave lower droplet mean diameter than the other orifice diameter at various levels of spray pressure. This may be due to the flow rate of orifice diameter $0.50 \mathrm{~mm}$ less than the flow rate of the other orifice diameter.

The results in this Table 3 clarified that the lowest values of droplet mean diameter was $(90 \mu \mathrm{m})$ by using spray pressure $200 \mathrm{kPa}$, orifice diameter $0.50 \mathrm{~mm}$ and forward speed $2.2 \mathrm{~km} / \mathrm{h}$. The highest values of droplet mean diameter were $(250 \mu \mathrm{m})$ at spray pressure $200 \mathrm{kPa}$, orifice diameter $1.5 \mathrm{nn}$ and forward speed $1.5 \mathrm{~km} / \mathrm{h}$.

\section{Percentage of damaged plants:-}

To calculate the percentage of damaged plant after using the transplanter mounted sprayer. By increasing the machine forward speed from 1.5 to $2.2 \mathrm{~km} / \mathrm{h}$ tends to increase the percentage of damaged plant from $0.87 \%$ to $0.92 \%$.

Table 3: Effect of orifice diameter and spray pressure on droplet mean diameter at two forward speeds.

\begin{tabular}{|c|c|c|c|}
\hline \multirow{3}{*}{ 总总 } & \multirow{3}{*}{ 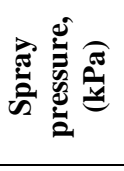 } & \multicolumn{2}{|c|}{ Average of droplets surface mean diameter $(\mu \mathrm{m})$} \\
\hline & & \multicolumn{2}{|c|}{ Forward speed, $\mathbf{k m} / \mathbf{h}$} \\
\hline & & 1.5 & 2.2 \\
\hline \multirow{4}{*}{0.50} & 22 & 190 & 172 \\
\hline & 300 & 173 & 150 \\
\hline & 400 & 150 & 115 \\
\hline & 500 & 121 & 90 \\
\hline \multirow{4}{*}{1.0} & 200 & 225 & 195 \\
\hline & 300 & 200 & 155 \\
\hline & 400 & 160 & 120 \\
\hline & 500 & 130 & 95 \\
\hline \multirow{4}{*}{1.5} & 200 & 250 & 210 \\
\hline & 300 & 210 & 170 \\
\hline & 400 & 180 & 130 \\
\hline & 500 & 140 & 100 \\
\hline
\end{tabular}




\section{Mortality percentage:-}

The fabricated prototype sprayer after development was tested in the field during the cotton spraying through determining the percentage of mortality. The impact of sprayer forward speed, orifice diameter, nozzle height and operating pressure on the percentage of mortality were conducted during testing the field performance of the developed transplanter sprayer as shown in Figs. (5 and 6). However, the maximum percentages of mortality remark to increase the uniformity of the spray pattern.

It can be seen that increasing the forward speed tends to decrease the obtained percentages of mortality for all the other variables. The sprayer forward speed of $1.5 \mathrm{~km} / \mathrm{h}$ recorded the highest percentage of mortality $(98.6 \%)$ for all the orifice diameter, nozzle height and operating pressures. The percentage of mortality decreased from $88.48 \%$ to $81.40 \%$ as a result of increasing the forward speed from 1.50 to $2.20 \mathrm{~km} / \mathrm{h}$ at orifice diameter $0.50 \mathrm{~mm}$, nozzle height of $400 \mathrm{~mm}$ and operating pressure of $200 \mathrm{kpa}$. This trend was due to the decrease of the uniformity of spray pattern with the high forward speeds.

The results indicated that the orifice diameter and operating pressure on the mortality efficiency under different levels of forward speed and nozzle height were shown in Figs. (5 and 6). It must be mentioned that both orifice diameter and operating pressure have a considerable effect on the mortality percentage according the Figs. (5 and 6). For all the sprayer forward speeds and nozzle height, the increase of both the orifice diameter and operating pressure tended to increase the percentage of mortality for the sprayer. The mortality percentage increased from $92.45 \%$ to $95.80 \%$ when the orifice diameter was increased from 0.50 to $1.50 \mathrm{~mm}$ at forward speed of 1.50 $\mathrm{km} / \mathrm{h}$, operating pressure of $200 \mathrm{kpa}$ and nozzle height of $700 \mathrm{~mm}$. On the other hand, it increased from $92.45 \%$ to $97.35 \%$ when the operating pressure increased from 200 to $500 \mathrm{kpa}$ at the same pervious variables with the orifice diameter of $0.50 \mathrm{~mm}$.

However, the orifice diameter of $1.50 \mathrm{~mm}$ and operating pressure of 500 kpa achieved the maximum values of mortality percentage for all the forward speeds and nozzle heights.

The percentage of mortality increased from 88.48, 90.15, 91.33 and 92.45 $\%$ at nozzle heights of 400, 500, 600 and $700 \mathrm{~mm}$, respectively, with forward speed of $1.50 \mathrm{~km} / \mathrm{h}$, orifice diameter of $0.50 \mathrm{~mm}$ and operating pressure $200 \mathrm{kpa}$ 

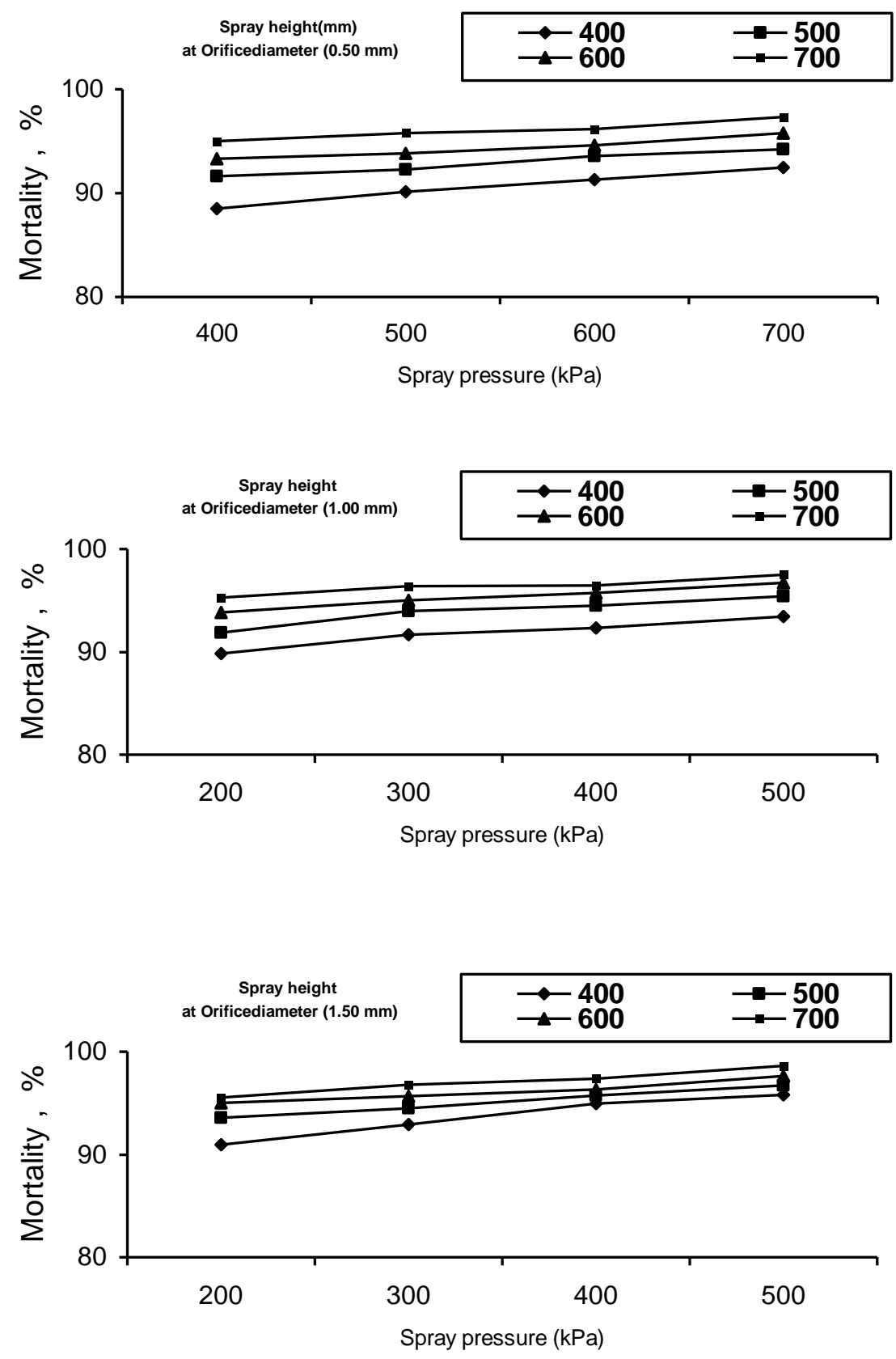

Fig. (5):- Effect of spray pressure, orifice diameter and spray height on the percentage of mortality at spray forward speed $1.5 \mathrm{Km} / \mathrm{h}$. 

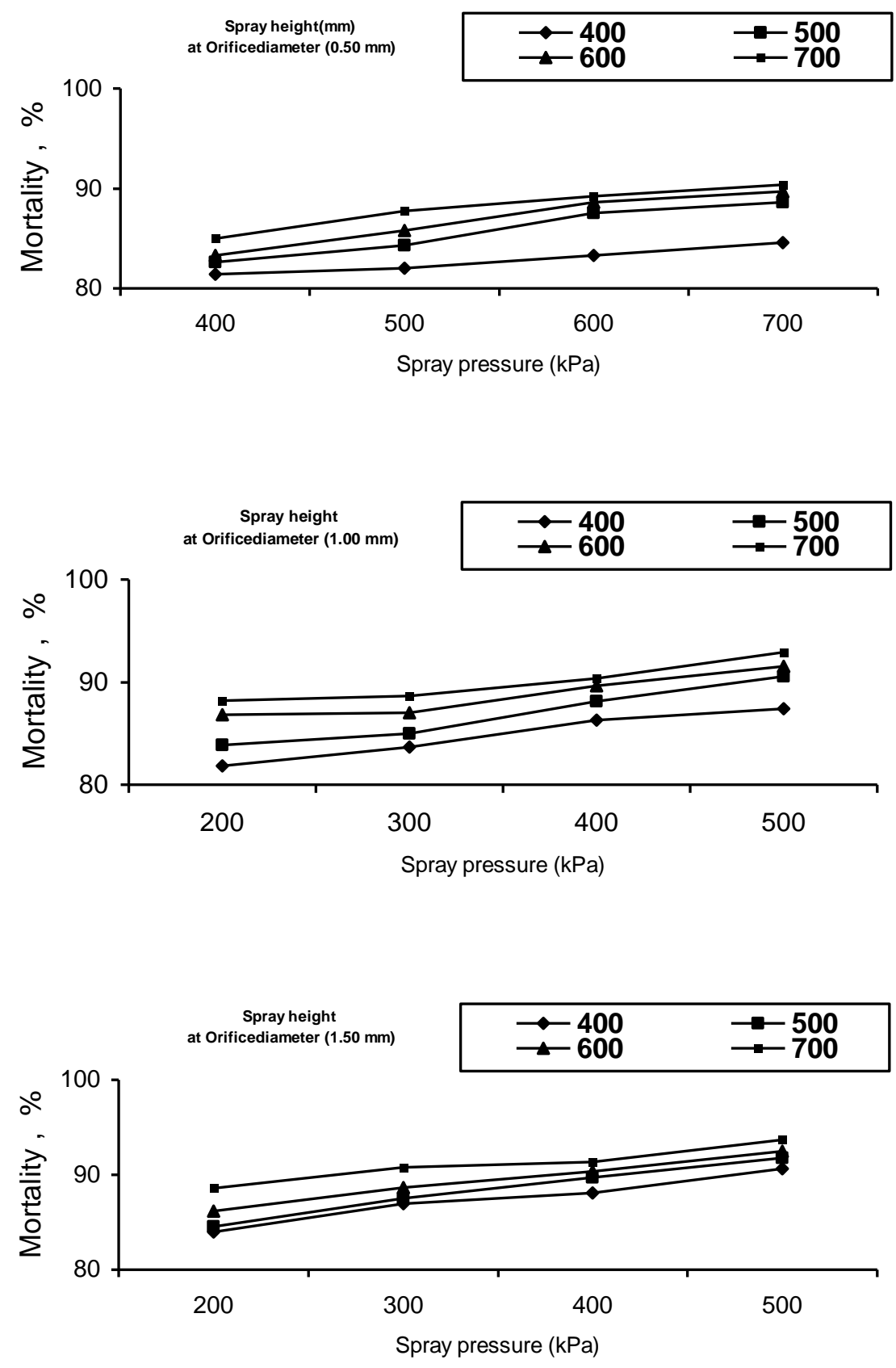

Fig. (6):- Effect of spray pressure, orifice diameter and spray height on the percentage of mortality at spray forward speed $2.2 \mathrm{Km} / \mathrm{h}$. 


\section{Field efficiency:}

To calculate the field efficiency of the transplanter mounted sprayer the following steps were followed:

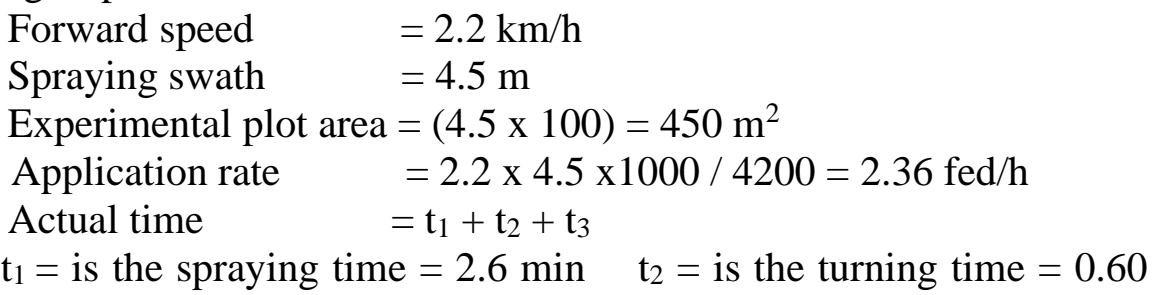
$\min$

$\mathrm{t}_{3}=$ is the filling time $=0.80 \mathrm{~min}$

Actual time $=2.6+0.6+0.8=4.0 \mathrm{~min}$

Theoretical time $=2.6 \mathrm{~min} \quad$ Field efficiency $=2.6 / 4.0 \mathrm{X}$ $100=65 \%$

Then the field productivity $=2.2 \times 4.5 \times 1000 \times 0.65 / 4200=1.53 \mathrm{fed} / \mathrm{h}$ Then the field productivity $=1.53 \times 6=9.18 \mathrm{fed} / \mathrm{day}$.

\section{Slip ratio, (\%):}

By increasing spray speed from 1.5 to $2.2 \mathrm{~km} / \mathrm{h}$ tends to increased the sprayer slip from 5.6 to $7.5 \%$. This agrees well with (Kamel and Elkhateeb, 2002).

\section{Energy requirements:}

Effect of forward speed on power consumed. The results showed that the power consumed reached 4.75 and $7.50 \mathrm{~kW}$ at forward speeds of 1.5 and $2.2 \mathrm{~km} / \mathrm{h}$. This agrees well with the results of (Kamel and El-khateeb, 2002).

\section{Cost analysis:}

The results indicated that the total fixed costs were $12.29 \mathrm{LE} / \mathrm{h}$ and the total variable costs were 8.18, and 9.26 LE/h with forward speed of about 1.5, and $2.2 \mathrm{~km} / \mathrm{h}$, respectively. While the total costs for spraying operation was 20.45, and 21.56 LE/h( 13.4 and 14.1 LE/fed ) with the same above forward speeds.

Finally, the minimum values of variation of coefficient(13.20\%) and the maximum values of symmetry coefficient $(95.50 \%)$ and coefficient of uniformity $(78.60 \%)$ were obtained with orifice diameter of $1 \mathrm{~mm}$, spray pressure of $500 \mathrm{kPa}$ and spray height of $700 \mathrm{~mm}$.

Also, the sprayer machine with forward speed of $1.50 \mathrm{~km} / \mathrm{h}$, orifice diameter of $1.50 \mathrm{~mm}$, nozzle height of $700 \mathrm{~mm}$ and operating pressure of The $16^{\text {th }}$. Annual Conference of the Misr Society of Ag. Eng., 25 July, 2009 
$500 \mathrm{kPa}$ achieved the maximum percentages of mortality percentage (98.6 $\%)$, minimum plant damage $(0.87 \%)$, energy requirements $(4.75 \mathrm{~kW})$ and total cost for spraying operation ( $13.4 \mathrm{LE} / \mathrm{fed}$ ).

\section{CONCLUSION}

\section{The study conducted to the following:}

The maximum values of coefficient of uniformity were 75.78, 78.60 and $77.22 \%$ at orifice diameters of $0.50,1.0$, and $1.5 \mathrm{~mm}$, respectively, with spray height of $700 \mathrm{~mm}$ and spray pressure of $500 \mathrm{kPa}$.

It is clear that the maximum values of coefficient of symmetry were obtained with the orifice diameter of $1.0 \mathrm{~mm}$ for all the spray heights and pressures. The highest values of coefficient of symmetry were 91.66, 93.16, 94.50and $95.50 \%$ at spray heights of 400,500,600, and $700 \mathrm{~mm}$, respectively, with spray pressure of $500 \mathrm{kPa}$ and orifice diameter of 1.0 $\mathrm{mm}$.

The maximum values of coefficient of uniformity were $78.75,83.15,84.75$ and $81.15 \%$ with nozzle spaces of 300,400,500, and $600 \mathrm{~mm}$, respectively, at spray height of $700 \mathrm{~mm}$ and spray pressure of $500 \mathrm{kPa}$. The maximum values of distribution characteristics were $91.66,94.60,96.70$ and $93.20 \%$ at nozzle spaces of $300,400,500$, and $600 \mathrm{~mm}$, respectively, under the same conditions.

The sprayer forward speed of $1.50 \mathrm{~km} / \mathrm{h}$ recorded the height percentage of mortality $98.6 \%$ for all the orifice diameter, nozzle height and operating pressures. However, the percentage of mortality decreased from 97.35 to $90.40 \%$ as a result to increasing the forward speed from 1.50 to $2.20 \mathrm{~km} / \mathrm{h}$ at orifice diameter of $0.50 \mathrm{~mm}$, nozzle height of $700 \mathrm{~mm}$ and operating pressure of $500 \mathrm{kpa}$.

The percentage of mortality increased from 91.90 to $95.48 \%$ as a results of using the nozzle height of 400 to $700 \mathrm{~mm}$ at the forward speed of 1.50 $\mathrm{km} / \mathrm{h}$, orifice diameter of $1.0 \mathrm{~mm}$ and operating pressure of $300 \mathrm{kpa}$.

The results indicated that the total fixed costs were $12.29 \mathrm{LE} / \mathrm{h}$ and the total variable costs were 8.18 , and $9.26 \mathrm{LE} / \mathrm{h}$ with forward speed of about 1.5, and $2.2 \mathrm{~km} / \mathrm{h}$, respectively. While the total costs for spraying operation was 20.45, and 21.56 LE/h ( 13.4 and 14.1 LE/fed ) with the same above forward speeds. 


\section{REFERENCES}

Badawy,M.E.(1997). Manufacturing a combined machine for cultivating, fertilizing and spraying field crops. Unpublished. $\mathrm{Ph} . \mathrm{D}$. Thesis.Ag.Mech.Dept., Fac.of Ag., kafr El-Sheikh, Tanta Univ.

Dragos,T.(1975). Farm machinery equipment hand book Ministry of Education. Bucharest, Romania. PP. 324.

El-Meseery,A.A. and A.A.Abd-El-Fattah (2005). Comparative study of two sprayers for controlling weeds in wheat crop. Misr J.Ag. Eng., 22 (3): 1059- 1069.

Gad,W.A. (2005). Automatic control of the boom height of a locally constructed sprayer for spraying the sugar beet crop. M.Sc.Thesis. Ag.Mech.Dept., Fac.of Ag., Kafr El-Sheikh, Tanta Univ.,Egypt.

Hunt,D. (1983). Farm power and machinery management. Iowa State University press, Ames, USA.

Kamel,O. and El-Khateeb, H. (2002). Performance evaluation of two different system of rice transplanter under Egyptian conditions. Egypt J.Ag. Res., 80 (3): 1317- 1335.

Noor,H.M.A.(1997). Improvement and evaluation of performance of ultra low volume sprayers. Ph.D. Thesis, Fac.of Agric. Mech. Dept.ElMansoura Univ.

Ozkan, H.E.; D.L.Rechard and K.D.Ackerman (1992). Effect of orifice wear on spray patterns from fan nozzles. Trans. of ASAE, 35 (4):1091-1096.

\section{الملخص العربي}

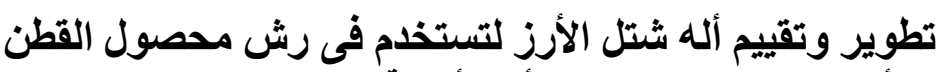

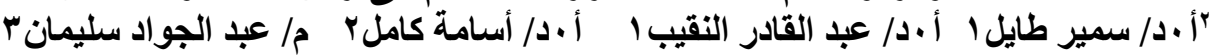

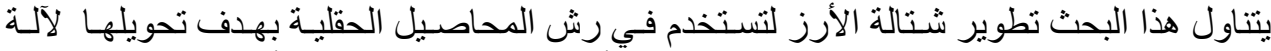

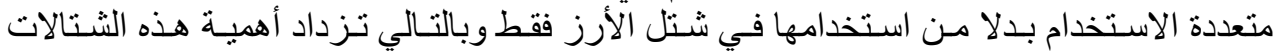

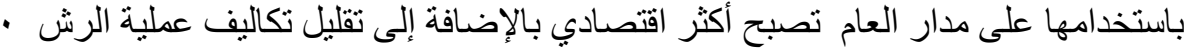

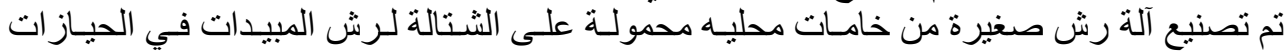

$$
\begin{aligned}
& \text { 1- ـ أستاذ الهندسة الزر اعية _ كلية الزر اعة - جامعة الاز هر }
\end{aligned}
$$

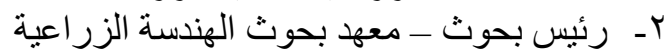

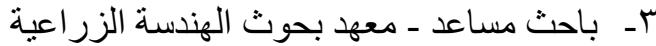




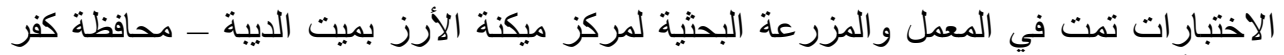

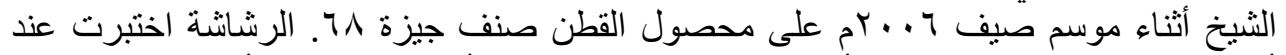
أربعة إرتفاعات للرش مختلفة و أربعة ضغوط للإل للرش وثلاث أقطار للبشابير و أربعة مسافات بين البشابير على حامل البشابير.

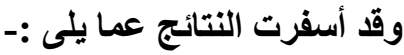

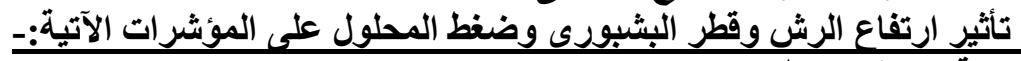

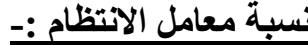

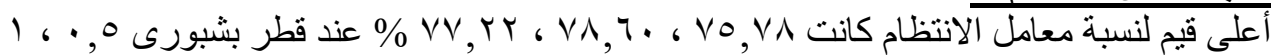

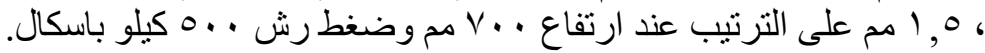

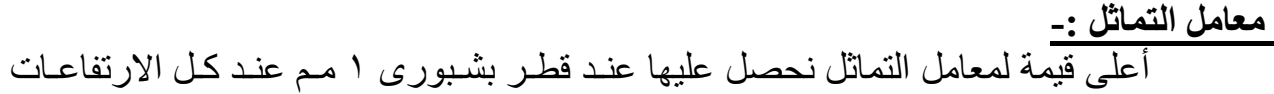

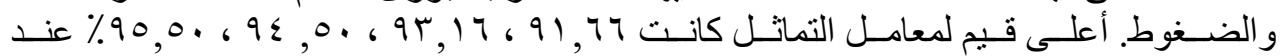

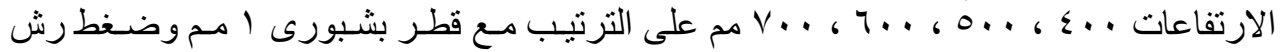

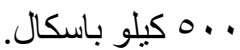

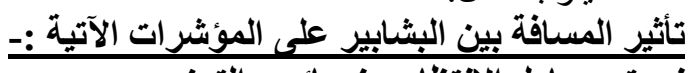

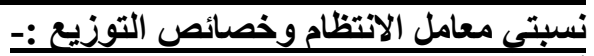

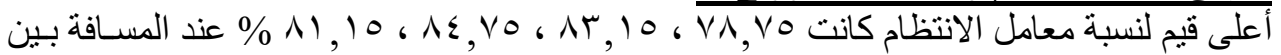

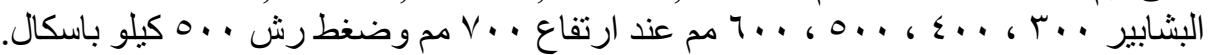

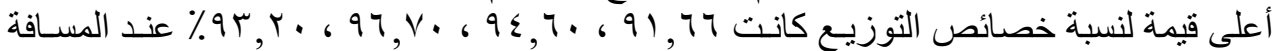

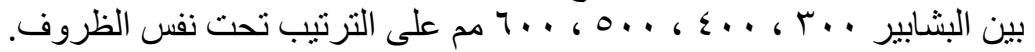

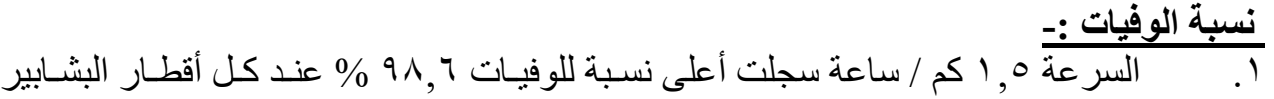

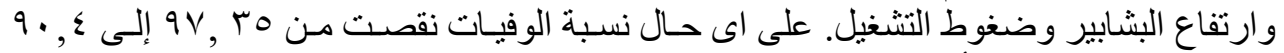

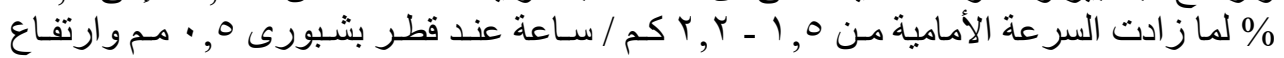

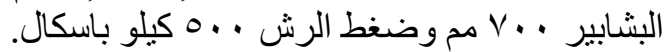

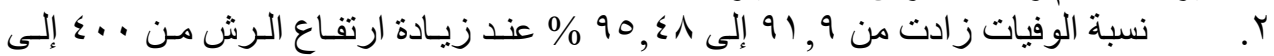

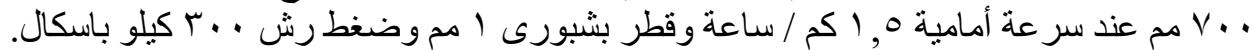

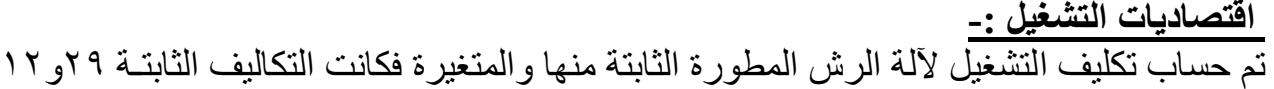

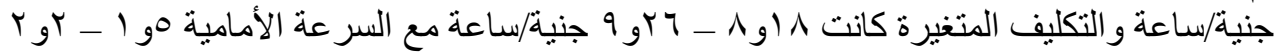
كم/ساعة.

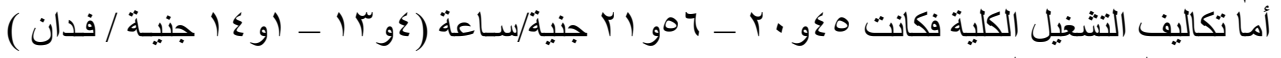
مع نفس السر عات السابق ذكر ها.

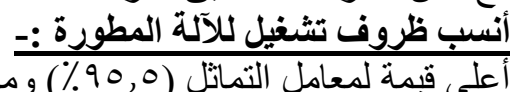

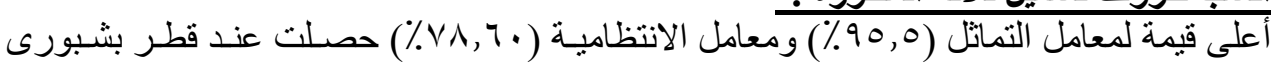

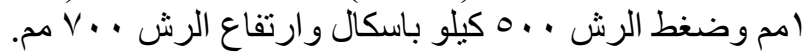

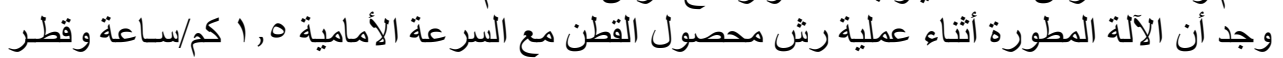

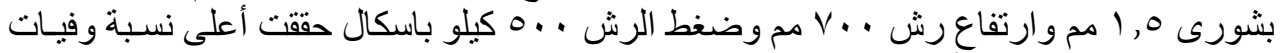

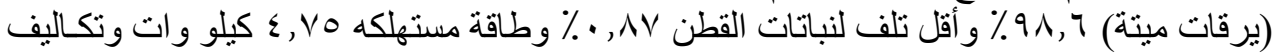
تشغيل لعملية الرش ع ربا آ جنية/فدان. 